\title{
JOVELLANOS EN EL SIGLO XIX: EL PROBLEMA DE LA REVOLUCION LIBERAL
}

\author{
Alberto GIL NOVALES
}

Aunque Jovellanos es fundamentalmente un escritor del siglo XVIII, le toca vivir en el XIX unos años decisivos, los iniciales de la Guerra de la Independencia, en puestos tan relevantes como vocal de la Junta Central, que van a adquirir una gran significación. Su nombre será con frecuencia utilizado, lo que no gustará al intercsado. Dirige una carta al Diario de Madrid (Madrid, 20 septiembre 1808 ), en la que protesta por la publicación de Copia de la representación hecha por D... a la Majestad de Carlos IV desde su destierro, Madrid Sancha (hay otra edición de Valencia, 1808'), que el Diario publica en el número 47 del 23 de septicmbre de 1808 (257-258).

Está claro que Jovellanos es lo que Ilamaríamos ahora un prohombre. Goza fama de persona representativa, eminente y venerada, no sólo por su labor intelectual de tantos años, sino también por las persecuciones de que ha sido objeto, que le dan en esa España en plena transformación aire liberal. Esta palabra no es exagerada, ni anacrónica. Cuando el general Horacio Sebastiani, corso como Napoléón, le invita el 12 de abril de 1809 a sumarse al bando lrancés, usa precisamente esta palabra. Le dice: «Señor: La reputación de que

\footnotetext{
Valencia, Faulí, 1808 (Palau, quien escribe 1880 por errata). Fied. Jovla ancs, Memoria en defensa de lo Junta Central, en Obrus. Colcceión hecha e ilustrada por Cándido Nocedal, nueva ed., Madrid, BAE, 1963, vol. I, Apéndice III, págs. 579-581 (en arlelante Obras, ed. Nocedal) y Lilian L. Rke, Biblingreffu erite de Jovellanos, Oviede, Cátedra Feijoo, 1977, número 328, con fa nota que le puso Josć (ano González. La calla al Dinro de Madrid uo está recogida en las Obras completas. Edición crítica, introdución y notas de José Minuel Caso Conzátez, Oviedo, Centro de Estudios del Siglo XVIII, 1984-1904 (en ardelante O.C.).
} 
gozáis ton Europd, vuestras ideas liberales, vuestro amor por la patria, el deseo que manifestáis de verla feliz y floreciente, deben haceros abandonar un partido que sólo combate por la Inquisición, por mantener las preocupaciones, por el interés de algunos grandes de España y por los de la Inglaterra. Insiste luego en «la libertad constitucional bajo un Gobieno monárquico, el libre cjercicio de vuestra religión», etc." En la muy conocida respuesta, fechada en Sevilla a 14 abril ale 1809. Jovellanos dice: "Yu no sigo un partido". y luego: «No lidiamos como pretendéis por la Inquisición, ni por soñadas pre. ocupaciones, ni por el interés de los grandes de España: lidianos por los preciosos derechos de nuestro Rey, nuestra religión, nuestra constitución y nuestra independencia ${ }^{3}$.

Retengamos de aquí que Sebastiani considera a Jovellanos liberal, en una fecha extraordinariamente temprana para tal término, que acaso no tenía todavía la plenitud de signiticado político que alcanzó después, pero desde luego iba en ese seutido ${ }^{*}$. A los otros dos corresponsales españoles de Sebastiani no les aplica el nusmo término de liberal, pero si a la Constitución de Bayoná. Sobre la respuesta de Jovellanos volveremos después. Ironía de la Historia, o aceleración de su sentido, estamos ante ur liberal que en 1800 se había asustado de la posible llegada a España de una traducción castellana de El Conrato Social.

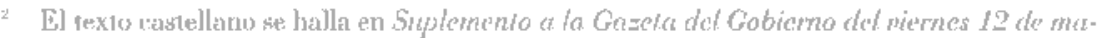

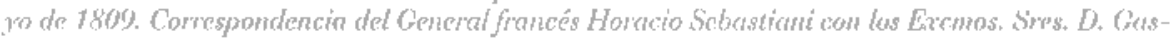
par de Jonellanos y D. Francisco de Satuedra, y con el Generat te anestro ejercito de la Curolina D. Francisco de Venegas, Cádiz, Oficina de Don Nicoláa Gómez de Requena, s.a., págs. 2-3. Las cartas de Sel)astiani no leven fecha. Consta en una nota cue fueron escrias en francés, "y lax traducciones que se publican verián inchuses en el nismo pliego con los originales. 'Tambien en José

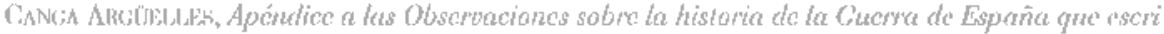

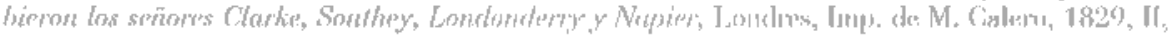

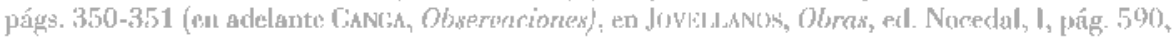
en Julio Somoza Dr: Monrsokm, Las amargatas de Jovellanos, [Gijón, 1889], Gijón, Editorial Au-

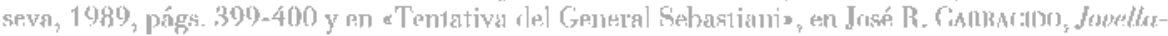

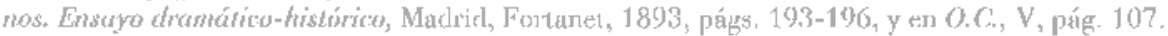

P'uede verse la contestíción en el Suplemento cit. en lé n. anterior, 2-3, en Caneca, obser-

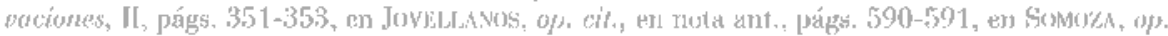

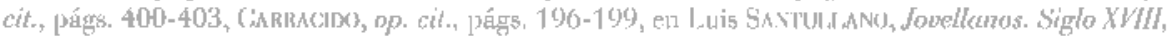

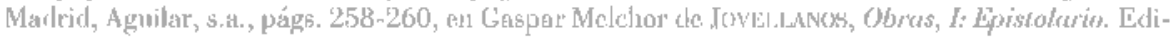

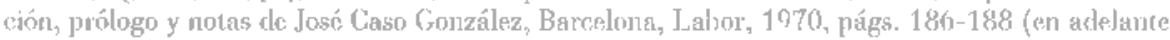
Epistolurio) y y en O.C., V, págs. 119-120.

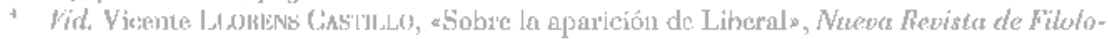
gia Hispánica, México, 1958, n." 12/1, páfs. 53-58, revoge plecisantente este ust por Selsastiant de la palatira adiberals.

lỉn la carcer a baevedra, pág. 4.

" Julio Somoza, Las amargumas de Jonelhos, cit., apéndice X, págs. 318-320. T'ambién en Obras, ed. de Miguel Arolu, BAF, 1. LXXXVIJ, Madrid 1950, págs, 342-343 (representación fecha- 
A los pocos meses de la muerte del asturiano, publica Isidoro de Antillón sus Noticias históricas de don Gaspar Melchor de Jovellanos, obra en lá que frente a la Corte corrompida de Carlos IV, se destaca el biografiado como «idólatra de la justicia», “investigador de la verdad» y «mártir de la libertad española», tal como ha visto muy bien el último editor de las Noticias, León Esteban $^{7}$. En el anuncio de este libro que se publica en el Diario Mercantil de Cádiz, se ponderan «los principales hechos de la vida pública y privada de Jovellanos, y los relativos a su largo cautiverio en Mallorca» y «otros muy importantes sobre la historia política de nuestra revolución durante el mando de la junta Central, sacando de todos las reflexiones convenientes para hacer más amable a los españoles el imperio de la constitución política y más aborrecible la tiranía bajo que hemos gemido por espacio de tres siglos con tanta mengua del espíritu nacional, de la felicidad pública y de las costumbress". En esta breve semblanza tenemos a un Jovellanos doceañista, que nos libra de trescientos años de oprobio. Así era visto.

León Esteban traza en breves páginas un cuadro muy acertado de lo que Antillón significó, aparte del mérito que tiene al haber puesto al alcance de todo el mundo un libro que ya se había hecho muy raro. Se esfuerza en su estudio en poner de relieve cómo Antillón no es un cco de la Revolución francesa, sino de lo que pudiéramos llamar la Revolución española. Nada más evidente, y sin embargo algunas expresiones pudieran inducir a error. Si consideramos que la Revolución francesa es el gran acontecimiento fundador, que cambia toda la historia del mundo, y que la revolución española nos aparece como algo caótico, inmaduro, y perpétuamente fracasado, podríamos pensar que Isidoro de Antillón no fue un escritor (y un político) revolucionario, y acaso precisamente que, por no serlo, escribió el elogio temprano de Jovellanos. Estamos ante un problema que parece nominalista, pero que no lo es. Me refiero a qué valor dar a la palabra Revolución, si significa lo mismo cuando aplicamos este término a la francesa, y cuando nuestros antepasados de la ćpoca de la Guerra de la Independencia hablaban de Revolución española. No resolveré yo ahora este problema, sólo lo planteo. En el caso del

da en Cijón, 26 marzo 1800, y rarias de Mariano Luis de Urquijo a .Jovellanus, particular y oficial, 2 y 3 abril 1800). Fit. monentario en Jefferson Ris Silst, Roussean in the Spanish World before 1833, New York, Cordian Press, 1969, págs. 165-166.

Isidoro ANItisón y Malrzo, Noticias históricas de Don Craspar Melchor de Jonellemos, edición y estudio de Lén Esteban, Universidad de Valencia, 1904, pág. 71.

* Diurio Mercantil de Cádiz, n“ 122, 1 mayo 1812, pág. 504. 
geógralo arayonés, no nació revolucionario (nadic nace revolucionario) pero su trayectoria vital le constituyó en un científico al día, que en una ciencia que entonces estaba constituyéndose, como la Geografía, conocía a todos los autores, incluso los más atrevidos e: innovadores, que habían tratado de su materia; un hombre que teníd sensihilidad moderna, que aspiraba a ser un ciudadano en sı país (esta palabra, sí, cen el sentido francés, citoyen) lo que sólo podría lograr mediante la desaparición de la vieja sociedad, y su sustifución por un mundo nuevo, presidido por una Cinnstitución o ley fundamental elabonala por unos diputados, ellos mismos originados en la bass popular. No oncuentro on Antilión la expresión «soberanía popular», pero es en 6l un concepto implícito. Naturalmente que esto se hace desde España, y para España, no podía ser de otra manera. Antillón y Jovellanos son dos ilustrados que abrazan la causa de la Revolución espanola, tal como nos ha veniclo por sus rauces históricos. Aunque los pensamientos puedan ser abstractos, las revoluciomes no se conchen desde la abstrueción, sino en las situaciones concretas que se van presentando, debidas a muchas causas, de índole intcrina unat, otras pot influjo externo.

Junto a importantes obras de Cieografia, de las que ahora no mo voy a ocupar, Antillón es el autor de ohras políticas, como íné es lo que más importa a la Espraña: Discurso de un miembro del populncho, Cádiz, 1808, Carta de un representante de Aragón a sas comitentes, Palma, 1810, Uttimas redamactones por la ratunable libertad de escribir durunte el gobierno de la Juma cenfral, 1810. Colección de documentos inéditos, pertenecientes a la historia politica de muestra revolución. Publicala con notas un miembro del pueblo, Palma. 1811. Cala de an arugonés residente en Mallorca a su amigo D. M. J. (). esfablecido en Cádiz sobre la necesidad de asegrarar con leyes eficaces la hibertad del ciudadrun eontra los atropellamientos de la fuerza amuda, Palma, 1811 , aparte los periódicos en los que intervino, el más inuportante de todos la Aurora Patriótica Mallorguina. Antillón es este micmbro del pueblo a del populacho, con aguda conciencia histórica del momento en que vive. Su Josellanos, lejos de ser nna excepción o estar en contradicción con esta serie de obras. pertence ('nteramente a cllas.

Tovellanos es pintado como el sabio homedo, el modelo a seguir, porque cuiso sicmpre al bien de la comunidad, mediante la educación y la acción poli1ica. Ina cuestión fundamental en aquella España de los comienzos de la Ciuerra de la Independencia ora la de llegar a la comvocutoria de unas Ciortes genarales. Antillón la defendió desde el principio, y vio con Jovellanos un campeón de lo mismon, que no ahomó esfuerzos para lograrlo. Incluso en esta mareria de la comvocatoria de Contes, llega a identilicar a Jovelianos con Cialvo de Rozas el 
autor de la Memoria nás decisiva, cono mienboro de la Jumta Cientral que era, sobre dicha convocatoria". Cuando Jovellanos escuchó la lectura de la Memoría do Calvo de Rozas, creyó que en clla se enconiraban "reproducidas y fomentadas" sus propias irleas ${ }^{10}$. Antillón pone de relieve la importancia del trabajo desarrollado por Jovellanos en la Connisión de Cortes de la lunta Cientral, sin que se dé excesivo relieve a la disparidad entre una convocatoria arcaica, por estamentos, que es la de Jovellanos, y la moderna, la que se hizo, es decir, la del voio por cabeza.

Antillón es también uno de los pocos que no sigue el coro general de diatribas contra la Junta Comral, que se desató en España después de su caída. No desconoce algunos de los principales errores de la Cientral, pero pasa sobre ellos simplemente con alguma alusión elegante. El restablecimiento del Consejo Real le merece tan sólo el comentario de que se hizo «no muy a propósito", al paso que reconoce que el crédito y autoridad de la Junta menguaban rápidamente". Esta suavidad en el juicio sobre la Junta Cientral sólo tiene una excepción: la de no haber lograto en dieciséis meses de actuación que a pucblo español gozase de una plena libertad de imprenta. Esto lo dice en las Noticias"', pero no acusa de ello a Jovellanos; y lo había dicho ya en los doloridos acentos de Úttimfts reclamaciones por la razonable libertad de escribir durante el gobierno de la Junta central, obra ya citada de 1810 , pero uemendamente moderna.

Con Antillón coincide en el significado de Jovellanos en cl origen de las Cortes Carlos Le Brun, aunque éste disimula menos cl lastre aristocrático del asturiano, pero lo fundamental está siempre en el tema de la convocatoria ${ }^{\text {: }}$.

Aunque sean obras tardías, conviene citar en este punto las Observaciones sobre la Historia de la Guerra de Lspaña de Canga Argüelles, en donde se dice: "Fortaleza indomable, exaltada consagración por la libertad de su patria, virtud cívica, e imperturbable resistencia a la tiranía donéstica, han sido las prendas que acompañaron a tan ínclito personaje hasta el sepulcro, adonde descendió colmado de las bendiciones de sus compatriotas, de las lágrimas agradecidas de la honrada pobreza, a quien socorrió con mano larga, y del respeto

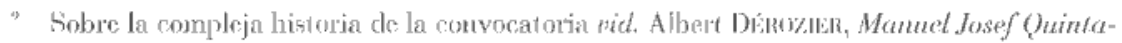

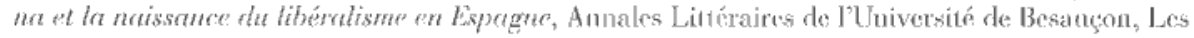
Belles Lelues, París 1968, págs. 457-512.

10 Noticins historicts, páng. 112.

Nolicios, pág. $11+$.

- Op. it. pág. 119 .

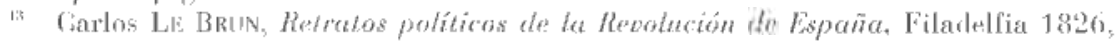
pigs. $260-202$.
} 
profundo de la nación ${ }^{14}$. Y el Examen histórico de la reforma constitucional de Argüelles, por su extensa utilización de Jovellanos en su razonamiento, y porque el autor, aunque conoce y cita la opinión de su conterrámeo en favor de las dos cámaras, no tiene empacho en escribir, tras citar un párralo de Jovellanos en favor de la libertad política de los ciudadanos: "En esta enérgica apelación a sus compatriotas expresaba vivamente aquel elocuente magistrado los verdadesos sentimientos de los hombres ilustrados de su era, y en ella presentaba como el programa de las miras y deseos que todos ellos tenían en su corazón, Henos de anhelo y esperanza de verlos al fin cumplidos por la sabiduría y fortaleza de las Contes: ${ }^{15}$. Aunque vanto Arguielles como Canga se hallaban ya en la uransición hacia el noderantismo, o hacia la franca racción, su testimonio es interesantr, por coincidir en el valor liberal que se da al asturiano.

Los autores del momento que atacan a la Jumta Central lo hacen en términos genéricos, y no suelen mencionar especílicamente a Jovellanos. Lo importante es haber logrado que sc convocasen las Cortes. Quizá nosotros no podamos damos cuenta de la immensa ansiedad que esta cuestión suscitó entre algunos españoles en los años inmediatamente anteriores a 1810 . Iabia demaslialas fuerzas negalivas en el ambiente, para que no se destacase el teson de lovellanos en lograr la convocatoria. Antillón, que es un firme partidario de las Cortes a la moderna, sabe que Jovellanos había intentado convocar una cámara alta, que la Regencia, escribe, "no quiso o no se acordó de poner en planta semejante cámara, al liempo de remir las Cortes; pues en estc caso no hubieran sido verdadera representación del pueblo sotberano, ni órgano ader.uado de. la voluntad general». Observenos de paso el lenguaje rousseauniano de Antillón, cl cual añade: «Sea así dicho en paz del mismo Jovellanos, el más decidido partidario de las dos cámaras y de los dos estamentos, creyéndolo conforme a nuestra Constitución antigua y a las preocupaciones políticas de la nación. Obraba por reglas de prudencia, y en asunto tan delicado no es de admirar que éstas lo mantuviesen más circunspecto y embarazado, de lo que sus mismos principios le hubicran permitido, obrando en abstracto, y según la bondad alysoluta de las cosas: it.

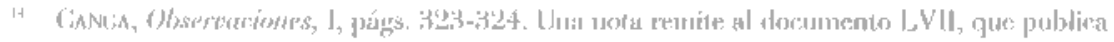

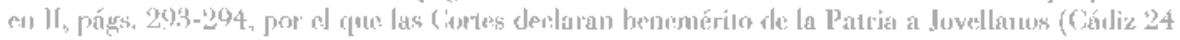

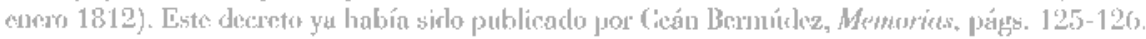

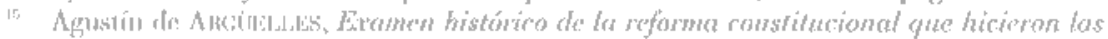

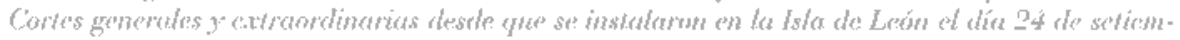

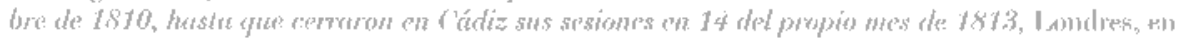

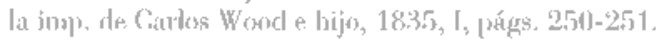

Noficios, pág. $120, \mathrm{n}$. 
El haber sido partidario de las dos Cámaras, que en la tradición liberal inmediata será el colmo de la reacción -piénsese por ejemplo en la época del Trienio liberal- no constituye en 1812, por lo menos en la pluma de Antillón, motivo alguno para la descalificación. Y esto no solamente por amistad o vencración, sino por aguda conciencia del inmenso desgarro que los hombres tienen que hacer para separarse del mundo antiguo, y crear uno nuevo. Por su propuesta de Cámaras, Jovellanos pertenece al pasado. Pero a la vez, por reclamar que se convoquen las Cortes, sin especificación, Jovellanos está abriendo el futuro.

Esto es del dominio público. Cuando el antor de la Carta sobre la antigua costumbre de convocar las Cortes de Castilla para resolver los negocios graves del Reino (Londres, 1810), sin firma, pero sabemos que no cra otro que Martínez Marina, enando este autor, digo, justifica las razones por las que escribe su Carta, el primer nombere que acude a sus páginas es el del "sabio y virtuoso" Jovellanos, quien apenas instalada la Junta Central solicitó la convocatoria de unas Cortes generales. Hizo algo más: escribió inmediatamente al propio Martímez Marina para que ilısirase sobre los usos españoles en la materia. Martínez Marina no hizo caso de momento, porque sabía que la Junta no pensaba en 1808 en tal convocatoria de Cortes; pero sí lo hace en 1810, cuando ya las Cortes están en marcha. Lo hace presisamente con el cncabezamiento de «stimadísimo amigo», es decir, esta Carta pública responde a la privada de Jovellanos ${ }^{17}$. Según (Cén Bermúdez la iniciativa de Jovellauos de escribir a Marúnez Marina se habría originado en una conversación mantenida en Zaragoza con José de Palafox ${ }^{18}$.

La doctrina de la Carta, basada y a la vez continuación del Lnsayo histórico-crítico sobre la antigur legislación y principales cuerpos legales de los reinos de León y Castilla Madrid, 1809), radica en la idea de que "en los bechos graudes y arduos se junten Cortess, y en que la Nación, ya aparece este con cepto, ante la auscncia del nonarca, es la única capacitada para resolver sus problemas mediante la representación política. Esta doctrina era, potencialmente, revolucionaria, aunque su autor la plantease con modestia. José Luis

17 Chrta sobre la antigna costumbre de convocar las Cortes de Castilla para resolver los ne-

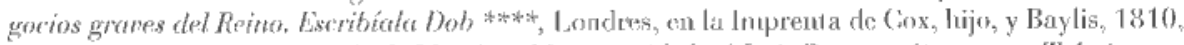
págs. III-IV y 1. Para lu autoría de Martínez Marina, vid. José Luis Blikmijo Cabrizer, éTríptico so-

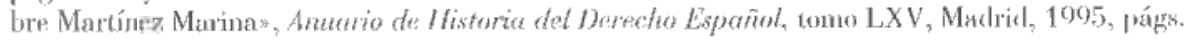
219-206, con seproducción del texto de la propia C'atta.

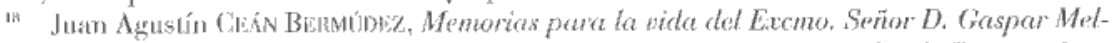
chor de Jove Lhanos, y noticias ancelificas de sus obras, Madrid, en la imp. que fue de Fuentenebro, 1814, pág. 90, obra dedicada precisamence a Palafox. 
Bermejo nos dice que Jovellanos recibió el "papel», el cual circuló abundantemente entre los miembros de la comisión o junta de Legislación, lo leyó Blanco White, quien después publicó un extracto o reseña en el número 1 de $E t E s p a-$ nol do lumdres, por lo cual curiosamente algunos autores modernos creyeron que Blanco White era el autor de la obra, y que ćsta no tenía otro texto que el publicado en El Español; la Carta sirvió al propio autor de iránsito hacia la Teoría de las Cortes e influyó tambiér sobre las propias Cortes de Cádiz. Todo en esta Carfa tiene arácter de urgencincia, porque la Nación no pucde esperar más. Aunque basada cn un pasado medievil y castellano, el antor sabe muy bien que

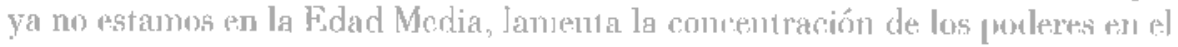
monarca, dire que en detorminades casos las Cortes pueden deponerlo, y no se pronuncia expresamente sobre la cuestión del voto, aunque como dice. Bermejo, sabe que éste tiene que ser bastante".

Como podemos ver, en el centro de toda esta cuestión está el noubre de Jovellanos. Insistiéé en lo que me parece lumdamentál: que on 1808-1810 era más importante lograr la convocatoria de Cortes que disentir sobre las modalialades de la misma. Jovellanos, por ello mismo, junto a otros, claro está, nos abre la historia antemporánea. Hasta 1810 lis ideus sobre la famosa convocatoria no se hau vuelto rígidlas, torlavía liay posibilidades de pase entre una y otra con-

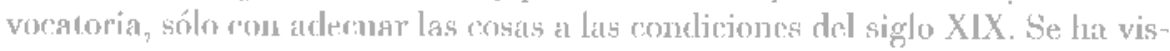
to que los partidarios de la irmovilidad no quicren Cortes. No se les ha visto todavía atrincherarse en los estanucntos, que es les que ocurrirí muy pronto. Pero creo que incurren en anacronisno los que dan a los valores del año $1810 \mathrm{y}$ anteriores, el mismo trataminto que al año 1820 y subsiguientes, cuando ya la Revolución amenaza, conando ya las aguas se bau plemamente deslindado. Por cierto que Céán fucrza un poco el sentido de las cosas, cuando dice que Jovellanos con su temprana idea de Cortes le pregunta a Martínez Marina «acerca del modo de convocarlas por estamentos $»^{201}$. Por lo menos, en ningún momento en la Carta de respuesua aturece tal palibreja, y se hace raro que si Jovellanos láa hubiese puesto Martínez Marina no la hubiese emplcado.

El mismo Antillón jecogió dos trabajus de Jovellanos son su Colección de rlo-

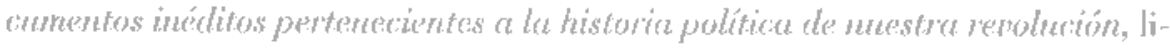
bro ya vitado antes. Son el número II, Parecer leido en la junta central pro su nocal D. Caspar de Jovellanos, sobre la forma futura del gobiemo. Octubre de

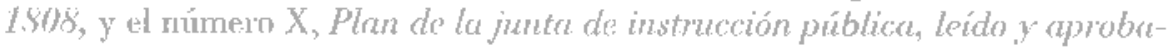

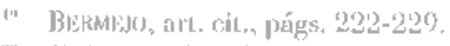

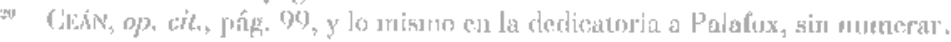


do en la de la comisión de cortes celebrada el día 16 de noviembre de 1809. Conviene que ahora nos detengamos en el primero de estos textos. Se trata de algo muy conocido, pues lo inchyó Jovellanos en el apéndice V de su Defensa de la Junta Central. El autor enpieza hablando de la importancia del tema, su repugnancia a escribir sobre el mismo por temor de que se le creyese ambicioso, o por el temor también a ser mal entendido, etc., son tantos los argumentos morales que Jovellanos emplea, que desde luego sobrecoge a cualquier lector. Pasa después a la parte expositiva"-1 que empieza de mancra tajante: «I. Ningún pueblo, sea la que fuere su constitución, tiene el derecho ordinario de insurrección». Ni lo tiene, ni se le puede dar. Esto es tan tremendo, que tomado en la plenitud de sus palabras, el principio anularía todo el esfuerzo de guerta español en la de la Independencia, en la cual el propio Jovellanos se halla comprometido. Pero el punto II va a anular al primero, no en su derlaración teórica, sino en la realidad de las cosas. Los acontecimientos van a modificar la inmutabilidad de los principios. Los franceses, al invadir España, y dejarla sin autoridades, han legitimado en clla el derecho de insurrección. Así todo el movimiento político español, insurrección general ${ }^{22}$, juntas provinciales, junta central, es perfectamente legítimo, como lo es tambićn el derecho que tiene la Junta Cientral a convocar (iontes.

Aunque pone después limitaciones a las facultades de la Junta Central, ya que en ella no está ni el poder legistativo ni el judicial, y aunque le prescribe la obligación de designar um Consejo de Regencia, el dato fundamental que se desprende de este informe es la legitimidad de rodo el proceso político español, a partir de 1808 , y por tanto también la convocatoria de Cortes. A pesar del carácter roumdo del primer principio, la realidad se ha impuesto, y Jovellanos acepta la teoría de la división de poderes, que en su día formulara Montesquieu.

La verdad es que vamos a encontrar siempre en Jovellanos algo que no sé si llamar bifronte o contradictorio. Hombre de su tiempo, ha vivido intensamente la Revolución francesa. Su reacción ante la misma ha sido ya nuy estudiada, sobre todo a través de su Dictio y de lo poco que ha quedado de su correspondencia con el cónsul inglés en Lá Coruña, Alexander Jardine ${ }^{2-1}$. Éste era

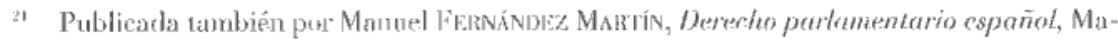
drid, Publicaciones del Ciongreso de los Dipuados, 1992, I, págs. 387 -401.

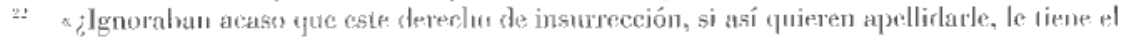

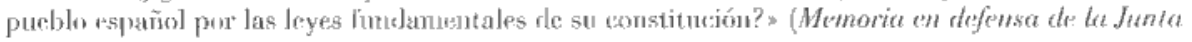
Centrel, obres, ed. Nocedal, XLVI, 5096).

2t Sigo en esta parte mi arúcule * Repercusión en España de la Revulución Fraucesa de 1789

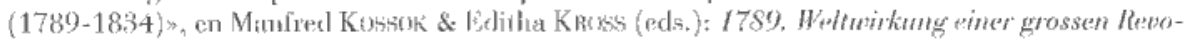
lntion, Bertiu, Akademie Verlag, 1080. II, págs. 401-420. 
un firme partidario de la gran Revolución, incluso en su fase jacobina. El poeta inglés Robert Southey, que conoció a Jardine. evoca en una carta desde La Coruña (15 diciembre 1795), la amistad del cónsul con Jovellamos, basada precisamente en sueños de progreso a través de la educación. Jardine es muy activo, según Southey, y Jovellanos no puede seguirle ${ }^{2 t}$. Edith Helman, hace algu$n 08$ años, estudió esta relación, aportando datos fundamentales sobre el inglés y las peripecias de su vida. La conclusión lógica fue que Jovellanos acabó por sentirse totalmente contrario a las idess de su amigo inglés, o, en palabras de la autora, Jovellanos «discrepa vadical y profundamente de los idcólogos revolucionarios franceses y de su corresponsal inglés, el cónsul Jardine ${ }^{25}$.

E1 tema requiere nayor consideración. En primer lugar, es gran lástima que hayamos perdido casi toda la correspondencia de Jovellanos con Jardine, probablemente porque, como supone la propia Helman, Jovellanos la destruiría por miedo de la Inquisicióni ${ }^{20}$. Y acaso también por la violenta expulsión de Jardine de La Cormĩa en 1799, que le acarreó la mucrte, sin que sepamos exac:tamente adonde fueron a parau sus papeles y sus libros, incluida una formidable colexción mosicale? De estas cattas mo han quedaclo más que los exiractos que el propio lovellamos insertó en su Diario, y la "Cimrta a desconocida persona» que Cándido Nocedal incluyó en su edición de la BAE, y de la que Ángel del Río dice, con razón, que sha figurado en toxtas las polśmiras solbe el liberalismo o el tradicionalismo de Jovellanos ${ }^{23}$.

La carra da mucho gue pensaten. Y es que las cosis no son tan sencillas. Jovellanos cra gran lector de roda clase de libres, por lo que podemos suponerle, una trayectoria ilustráda próxinta al mundo que cngendró la Revolución. Algunos tox dos asi nos lo harian frensar, como esa entrada de su Diurio del 4 de marzo de 1794:

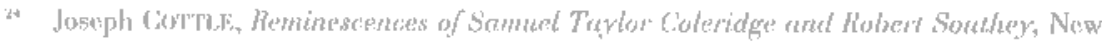

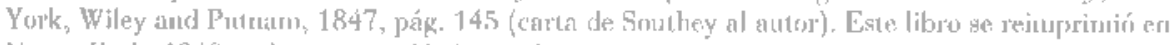

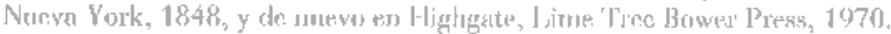

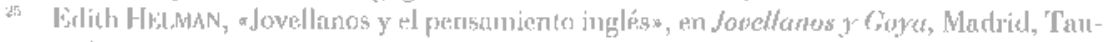

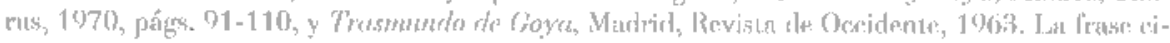
cada, cn este segumlas libro, pág. 107.

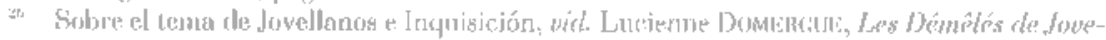

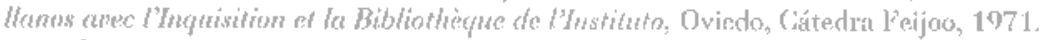

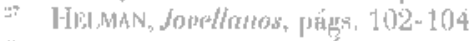

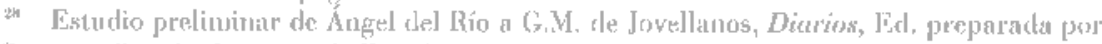

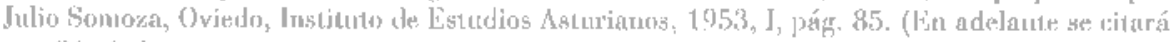
por Diariosj.

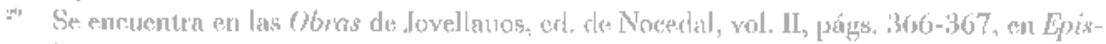
bolarif, júgs. 80-02, y en O.(., II, ]’ígs. 634-638. 
«Respuesta a Jardines. Educación; remover estorbos a la circulación de las ideas; los mayores, de la política, asustada por los progresos de la razón »*0.

Cierto que esto es todavía una posición de ilustrado: pero en la fecha en que se escribe resulta muy llamativa. No obsamus el 3 de junio la cosa parece clara:

a Carta a Jardines para el correo de mañana: "que nada bucno se puede esperar de las revoluciones en el Gobierno, y toulo, de la mejora de las ideas; que por consigniente deben proceder de la opinión general; dos consecuencias: primera, contra Mably, que defiende la justicia de la guerra civil; segunda, contra el mismo Jardines, que mira el espíritu de revolución como distintivo del mérito. Que pienso, con Fox, que el ejemplo de Francia depravará la especie humana: prueba, en la Polonia, que tiene ya su Tribunal revolucionario. Que la idea de: la propiedad común, se debe proponer como una teoría. Que el electo de la guerra será: pizmero. Francia quedará República, pero débil, turbada, expuesta a la tiranía militar, y si vence, recobrará luego sı esplendor'segundo, la Inglaterra, sabia y ambiciosa, aumentará su poder con colonias: su gobierno serri turbato y sangriento por la mecesidad de conservarlas, y su grandeza, sümpre precaria; tercero, las demás potencias, extemudas; pero si, escarmentadas, prefieren la paz y protegen las artes pacílicas, y sobre todo, la agricultura (la única que puede solidar su poder), evitarán su ruina ${ }^{n}$.

Unos días después, el 19 de junio, al recibir carta de Jardine:

«no me gustan ya sus ideas políticas, y menos las religiosas; distamos immensamente en uno y otros.".

Y todavía el 26 (siempre junio de 1794):

«A Jardines, que no apruebo sus ideas religiosas, ni es posible dejar de reconocer las que predica la natural za y abraza tan agradablemente la razón, ni tampoco las que defiende Mably, cuya opinióm, en cuanto a guerra civil, detesto. Que jamás creeré que se debe procumar a una Nación, más bien del que

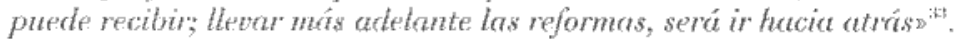

Estas primeras cartas, o resúmenes de cartas, merecen algín comentario. Se advierte en Jovellanos un doble plano: el de las ideas, en las que admite incluso la propiedad común, que habrá leído en Godwin, y el de la acuación práctica, en el que se muestra muy receloso e incluso negativo, no aparentemente por lo que la revolución demanda, sino por los métodos, porque todo se estro-

Wo Dirrio, I, pág. 306.

a Dirrio, 1. púgs. 436-437.

traturio, I, jốg. 442.

(2) Dínier, I, pág. 446 . 
pea, por las consecuencias, etc. El rechazo de Mably, es decir de lá doctrina expuesta en Derechos y deberes del ciudadano, indica acaso lo mismo: Iovellanos rechaza la violencia para conseguir la liberación, en lo cual se diferencia netamente del pensamiento posterior español, el de los comumeros del Trienio, incluido Juan Romero Alpuente ${ }^{34}$.

Estas premisas explican también el rechazo de Robespierre. El 6 de agosto de 1794 escribe:

«(inrren: a Jardines; pstablecer el diapasón de las icleas para proceder de muas en otras; dificultad rle aconodar el gobierno democrático a los grandes dominios, probado con el ejemplo de Ruma aplicado a la actual situación cle la Francia, verdaderamente tiranizada por Robespierrex ${ }^{i 5}$,

en lo cual Jovellanos no hace más que seguir urı conocida idea de Montesquieu, sobre que las repúblicas deben ser por naturaleza de corto territorio ${ }^{\text {at }}$; en cuan10 a la comparación de Francia con Roma procede seguramente de su admirado Gibbon, tantas veces citado con elogio en el Diario, el cual lo mismo que Ferguson, según Momigliano, sólo pudo concebir su Historia después de la guerrá de Independencia de los Fstados Lridos.7.

EI sentimiento de desolación de Jovellanos (en el que no falta una nota parifisla, enemiga por tanto de la guprra contra la República francesa) va creciendo con el paso lento del tiempo. El 3 de septiembre le escribe a su amigo inglés

aque sa desconfie de los frecthinkers, no le suceda lo que con Durango; (rre no quiero correspondericia con ellos, ni pertenecer a ninguna secta; que no temo por la seguridad pública; que no hay más medio que mejorar la opinión pública por los medios que ella permita: lo denás, es causar la desolación de los mismos a yuienes se quire consolar; que es bueno todo Gobierrio que asegure la paz y el orden internacional; que no hay alguno que no esié expuesto a inconvenientes; que los de la democracia están demostrados con el funesto ejemplo de la Francia, gue no hay que esperar de clla la reforma del nundo;

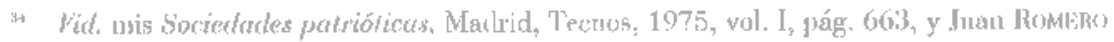

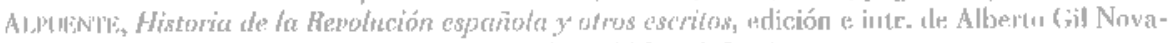

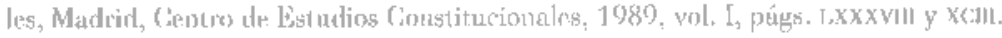

") Dissro, I, pág. 470.

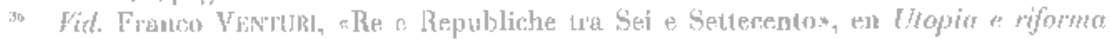
nell Whaminismo, Torino, Einaudi, 1970, pág. 50 . El 18 do sejstiembre de 1794 Jovellanos escribe: * Jardines dice aue hay gran cuidado entre sus ministros: temen el grat porder de la República y su enorme extesjón (Dicurio, I, pág. 488).

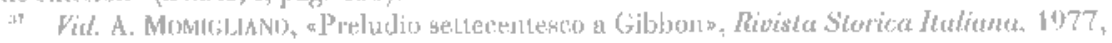
I, pág. 10. 
le van barbarizando: nna secta sucederá a orra en la opresión, y la estúpida imsensibilidad, hija del terror', los liará sufrirn" ${ }^{38}$.

En todos estos juicios está Jovellanos bajo la conmoción de lo inmediato. las noticias que llegan de Francia, o sobre Francia, en las que no dejarían de tener su parte la lectura de Barruel, y la de las cartas de Teresita Cabarrús, hija de su gran anigo el ĺuturo ministro josefino, persona de escandalosa vida en el Burdeos revolucionario, como unida que estuvo con Tallien. Dos cartas de ella dice haber recibido el 5 y el 15 de octubre de $1795^{32}$.

Finalmente el 23 de febrero de 1796 , apunta Jovellanos en su Diario:

* Carta larga a Jardines, entrando, en fin, en hablar de sus sueños filosóficos; dígole crus, por la última vez, mi poca afición a cllos, poco ticmpo, etc.; quedará copia ${ }^{+1}$.

Edith Helman, con referencia a Goya, identifica estos sueños de Jardine, vistos por Jovellanos, con el Terror revolucionario y los Caprichos del célebre aragonés (Et sueño de la razón engendra monstruos) ${ }^{+1}$. No es uccesaria esta identificación que, por supuesto, no es histórica, sino meramente interpretativa. Otra cosa sería decir que Goya fue el auténtico testigo intérprete de su época y por ello de la Revolución francesa ${ }^{+2}$.

De intento he dejado para el final la única carta a Jardine que poseemos completa, la que Cándido Nocedal tituló "Carta a desconocida personas, y que Polt fecha en Gijón a 21 de mayo de 1794.". En ella, después de estar de acuerdo con su corresponsal en la necesidad de climinar a la Inquisición, o dejarla por lo menos sin poder, Jovellanos dice netamente: «Vd. aprueba el espíritu de rebelión, yo no", e insiste en su desacuerdo fundanental con Mably. No obstante, el sistema de Godwin (es decir, la comunidad de bienes) le atrae, es desde un punto de vista ideal el más perfecto. Sólo que no es un sistema que esté ya vigente, y por tanto para su mentalidad es un sistema imposible. Jovellanos cree que hay que ir poco a poco, e insiste mucho en el progreso gradual. El pensamiento de Jovellanos, empero, cuando parece abandonar una idea la vuclve a coger, acaso bajo otra forma. El meollo de esta carta está en el siguiente párrafo:

\footnotetext{
s. Diario, I, pág. 4833.

31) Derrió, Il, págs. 169 y 171.

(4) Diario, II, pág. 221.

" Jelman, Transmundo de Goya, pág. 152. tia, 1958.

t2 Vich. Miroslav Mroko, «Emleitung*, a Francisco Goya y Lucientes: Caprichos, Praga, Ar-

73 Vit. John II. R. ProLT, «Ua nota jovellanista: Carta a desconocida personas, en /lomenaje al Prof. Rodríguez Moñino, Madrid 1960, vol. II, págs. 81-86. Fíd. Miguel S. Ordvirir, Hojers del súbado, II, Revisiones y Centenurón, Barceloua, Gustavo Cili, 1919, págs. 8-12.
} 
* ¿arécele a usted que sería poca dicha nuestra pasar al esiado de luglaterra, conocer la representación, la libertad política y civil, y supuesta la división de la propiedad, una legislación nás protectora de ella? Cierto que sería yraude, por más que estando en ella tuviésemos derecho de aspirar, no al sistema de Godwin, sino, por ejemplo, a una constitución cual la que juró Iuis XVI en 1791. jVe usted el inmenso copacio que hay entre una y or ra, entre la última y la del 93\% ;Y acaso ésta toca en el eslabón labrado por Godwin? No halbrá otros muchos intermedios? Creo que sí»"4.

Después sigue predicando que cada nación progrese en su sistema, y que se construyan caminos, canales, etc., y se consiga una agricultura próspera. Pero pensar que en su fuero interno, sirn más excepción que la comunicación al amigo extraino, Jovellanos renunciando al sistema de Codwin pensaba en lo bueno rfue sería para España el sistema representativo, una Constitución, por ejenplo, como la francesa de 1791 -modelo principal, como se sabe, de la española de 1812- nos antoriza a pensar en un Jovellanos liberal, y casi en uru revolucionario recóndito. Uno piensa en el elogio posterior de las revoluciones españolas, sin sangre, y en el contagolpe reaccionlurio, siempre sangricnto, y no [mede menos que lamentar la hispánica bortuonía de Jovellanos ${ }^{+5}$. Fl cual, gran lector, siguió devorando obras progresistas y demócratas, algunats conseguidas a través de. Iardinc, ot ras no. En su Diorio aparecen Tocke, Ferguson, Payne, Rousseau y otros: coincide con unos, discrepa de otros, pero no techaza a priori a nadie.

Patriota, lovellanos lo fue siempre, y después de las persccuciones de que fue objeto, lo refrendó en 1808 negáandose a colaborar con los invasores ${ }^{\text {th }}$. Fss conmovedor leor al comienzo de su Memoria en defensa de la Junta Central sus no disimuladas palabras en favor de la libertad:

«Por fin, Ia nación española se va a juntar en cortes. El real decreto que las anumcia para el próximo agosto se lace ye con entusiasme ten lockas partes"s. [...] « y la voluntad de todos los padres de familia cque luabitan los vastos continentes de una y otra España va a ser declararla en este augusto congreso, el nás grande, el más libre, el mús espertable que pudo concehirse para fijar el deatino de una nación tan ultrajada y oprimida en su libertad, como magnánima y oonstaute en el empeño de delenderlas

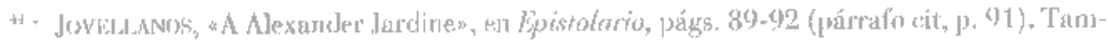
biću ell (). (. vol. II, págs, 0.34-638

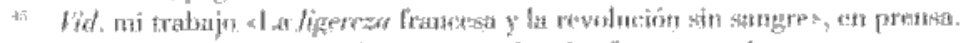

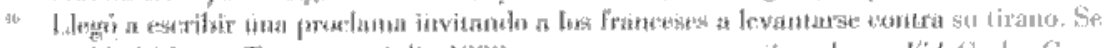

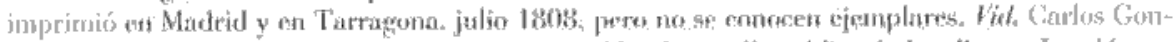

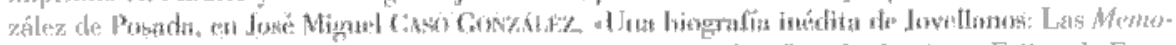

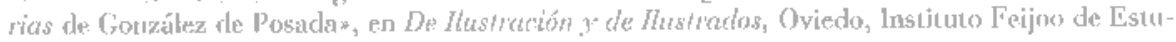
dios del siglo XVIII, 1988, pág. 198. 
Jas palabras son magníficas. Jovellanos añade: «Al contemplar esta grande idea, mi corazón salta en el pecho de alegría, viendo acercarse el momento que tan ardientemente babía deseado». Y cuando pasa a hablar de sus quejas, de la necesidad de ser oído y desagraviado, no se dirige a los representantes de la nación, no a clero y nobleza y diputados de los pueblos, sino a la nación toda: al juicio inapelable de la opinión pública, representada en "todos y cada uno de los miembros de la sociedad en que vivo ${ }^{+7}$. Es decir que, idealmente, Jovellanos procede a una especie de leva en masa nacional en favor de su virtud, mientras que la práctica política va por los derroteros gradiales y prudentes de siempre. Como ya he dicho, la convocatoria a Cortes, redactada por él, lo era por estamentos. No vivió lo suficiente para ver aprobada la Constitución de 1812, y no podemos saber por tanto si su promulgación le hubiese arrancado las mismas cntusiastas expresiones que la palabra misma. En agosto de 1811 , en carta a su sobrino Alonso Cañedo y Vigil, arzobispo de Burgos y diputado, se pronumcia contra el dogma de la soberanía nacional, sancionado en las (iortes, «dogma que puede llevarlos [a los diputados] a perpetuar la forma democrática en que ustedes se han constituido, y a dejar sin garantía la Constitución que hicieron ${ }^{t+}$. E] razonamiento en este punto es, que si se admite que las Cortes de Cádiz cambien por otra la Constitución histórica española, la nueva Constitución también podrá ser revocada por una nucva asamblea. Esto es, evidentemente, lo que ocurrió en España a lo largo del siglo XIX, pero se trata de un resultado inevitable; y en cuanto a eso de la Constitución histórica ${ }^{40}$, tan del agrado de un sector de la crítica, resultaba del intento de poner límites al absoJntismo real, función que en Francia ejercieron los Parlamentos ${ }^{501}$; y también esa idea obedecía al criterio de señalar precedentes al constitucionalismo de 1789 y al de encontrar rasgos nacionales constantes a lo largo de los siglos anteriores. Sabemos que Jovellanos llegó a leer el proyecto de Constitución, al que opone grandes reservas, pues «el dogma de la soberanía nacional, en el sentido en que

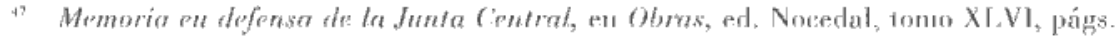
$504-5000$.

th Carta a Alonso Cañedo y Vigil, sin ferhar, en la ed. de Nowedal, págs. 376-377, lechada

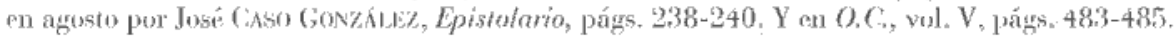

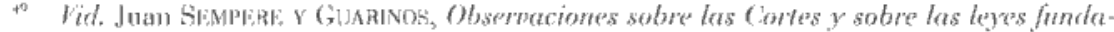
mentales de Españe, Granada, 1810. El mismo, Memorias para la historia de las Canstituciones

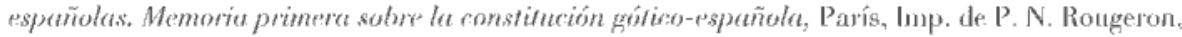

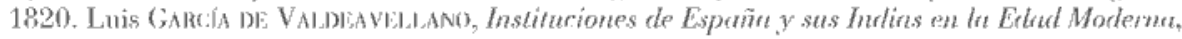

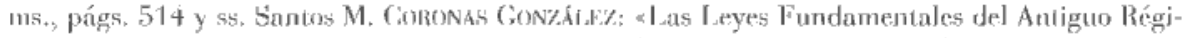
men (Notas sobre la Constinución histórica española)s. Anuario de Historia del Derecho Español. tomo I,XV, Madrid, 1995, páss. 127-218.

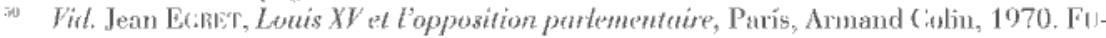

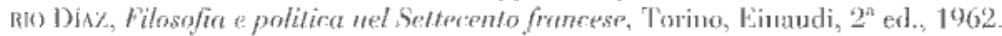


está concebido, la exclusión de la representación a los estamentos privilegiados, y la reunión de los representantes en una Cámara y para una sola deliberación. son cosas del todo ajenas de la buena y sana política». Su modelo es Inglaterra, con las dos cámaras de los Comunes y de los Lores, y la democracia federal de los Estados Inidos, con el Senado frenando los excesos del Congresoñ.

Este modelo, y las íntimas dudas de Jovellanos entre la rectesidad de la reforma y el temor a llevarla demasiado lejos, explican que Don Juan Valera, observador distante pero muy inteligente, pudiera decir, después de hablar de las persecuciones de que habia sido objeto Jovellanos: « recelo que lovellanos, si más hubiera vivido, hubiera tenido que ver y que sufjó cosas mucho perores: sospechoso o culpado de liberalismo, de 1815 a 1820 hubiera ido a la emigración, de nuevo al castillo de Bellver o quizás al presidio de Ceuta: y desde 1820 a 1823 no es extraño imaginar que le hubieran perseguido, silbado y tal vez apedreacto por lanático, clerical y oscururitistas".j.

No hay que tomar este futurible, imaginado por Valera, como si luese la verdad histórica. Lo traigo a colación sólo porque señala, de forma eminente, las contradicciones que suelen verse en Jovellanos como sujeto histórico. Ls demasiado frecuente, en nuestro país, hablar de jóvenes preclaros, que nurieron en la flor de la edad, de los que se predica que, si no hubiesen muerto, se habrían transformado en tal y cual,.. alguna ignominia. Creo que pensar así es profundamente injusto. En lo único que tienen razón los que así razonan es en que si los jóvenes 10 mueren jóvenes, llegarán a viejos. Pero esta perogrullada nada tiene que ver con el mundo moral, que es el que, con su razonamiento, trataban de desprestigiar. T'ambién Somoza dice que, de haber vivido Jovellanos más allá de 1814, tras el decreto del 4 de mayo de este año, se le habría enviado de mevo a Bellver:

Volviendo a Jovellanos, c1n una carta a Cabarrús, llegó incluso a cutrever la posibilidad de un sistema republicamo para España ${ }^{-i »}$. En lu canta, fouhada er daArarpe en septiembre de 1808, le dice al antigno amigo, alnora ya aframesarlo:

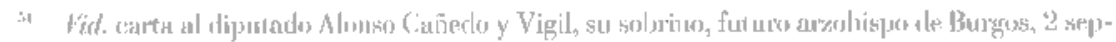

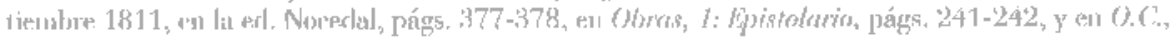
V. pángs. 485-480.

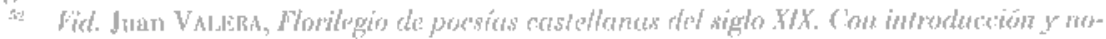

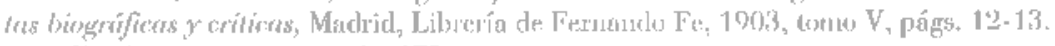

.i fors amarguras..., pág. 179.

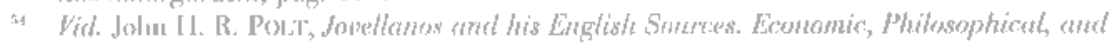

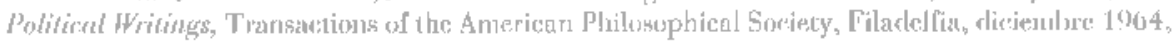
pág. $00^{\mathrm{t}} \mathrm{u}(\mathrm{s}$. 
«España no lidia por los Borbones ni por Fernando; lidia por sus propios derechos, derechos originales, sagrados, imprescriptibles, superiores e independientes de roda familia o dinastía. España lidia por sn rcligión, por su Constitución, por sus leyes, sus costumbres, sus usos, en una palabra, por su libertad, que es la hipoteca de tantos y tan sagrados derechos. España juró reconocer a Fermando de Borbón; España le reconoce y reconocerá por su rey mientras respire; pero si la fuerza le detiene, o si la priva de su príncipe, „no sabrá luscar otro que la gobicne? Y enando tema cue la ambicion o la flaqueza de un rey la exponga a males tamaños como los que ahora sufoe, juo sabrá vivir sin rey y gobernarse por sí misma?’"

Tiene razón Polt: la última frase transerita equivale a una declaración, eventual, de republicanismo. Inmediatamente queda servida la polémica. El propio Polt recuerda que Sánchez Agesta rechaza tal posibilidad ${ }^{53}$, mientras que Cumersindo de Azcárate e l Iilario Yaben la habían admitido ${ }^{57}$. Pero es curioso que el historiador clásico del partido republicano español, Enrique Rodríguez Solís, coloque a Jovellanos en la Junta Central a la cabeza del partido reformis1a, junto a Calvo de Rozas, el partido que logró la libertad de inprenta y la con-

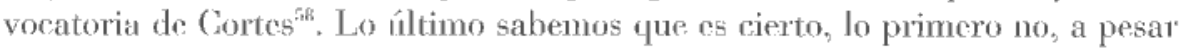
de la proclamación oficial: en caso contrario Antillón no lo hubiese denunciado. También Quintama en 1810 protesta de que, al cabo de dos años de revolución, todavía no rengamos libertad de prensa ${ }^{\text {so }}$.

Pero observemos que la carta de Jovellanos es, como ya se ha indicarlo, respuesta a Cabarrús, es decir, un compatriota que ya había cambiado de dinastia. Lo cual, en el momento concreto en que contesta al antiguo amigo, le sirve para librarse él también, por lo menos idealmente, del mito fernandino, y llegar hasta ma concepción republicana. Conviene que nos demos cuenta de la fuerza inaudita que tuvo el mito fermandino, el del príncipe cautivo, el príncipe que sulre, en el que se ve la felicidad futura de toda la Nación. Esi éste um mito que

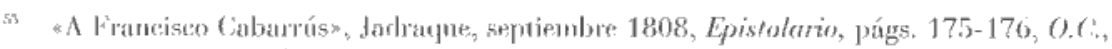

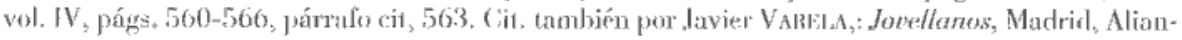
za, 1988, pág. 204.

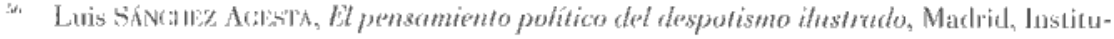
10 de Esiudios Polílicos, 1953, pág. 225.

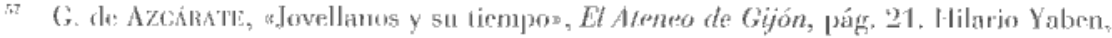
Juicio crútico, Madrid, 1913, pás. 230 (cilas de Polt, op. cit., nota 24, que no he podido verificar').

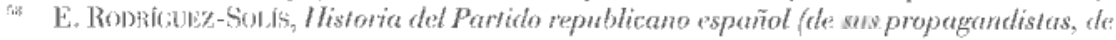
sus tribunos, de sus héroes y de sus mirtives, Madrid, lomp. de Fermando Cigo y Domingo de Val. 1893 , vol. II, pág. 104.

59 Virl. M. J. Q. [Manuel José QunTaNa], aDisemso de un español a los diputados en Cortesx, Cádiz 14 setienbre 1810, A Observalor, n"14, viernes 21 seliembre 1810, pris. 220. (El Discurso ocupa 10 do el número). 
todo lo arrastra: de él participan los reaccionarios y los progresistas, el propio Jovellanos en otras ocasioncs, Antillón, Romero Alpuente, el gran diputado americano Mejía Lequerica e incluso los propios insurgentes del Nuevo Mundo, que llegan a felicitarse de que Fernando VII, brutalmente, destruyese en 1814 su propio mito, porque de haber persistido en él habría sido imposible la Independencia de América ${ }^{60}$.

Fn una serie de cartas a Lord Holland Jovellanos precisa más su posición ante el problema do las Cortes. En primer lugar, cl 2 de noviembre de 1808 , de acuerdo con todo lo que ya se ha dicho aquí, la necesidad imperiosa de remir las Cortes. Y en seguida, para orientación de su corresponsal, le manda el Ensayo hisfórico-critico de Martínez Marina. Esto cs congruente con la admiración que mutuamente se profesaban y con el urigen de la Carta, ya citada, sobre la antigut costumbre de convecar las Cortes; pero a la vez el nombre de Martínez Marina prolonga idealmemte hacia la modernidad el pensamionto do Jovellanos. En la misma carta se cita a Floridablanca conuo «poco inclinado a la convocación de Cortes»". El gobierno, dice en otra oceasión, debe contar con el pueblo. No di-

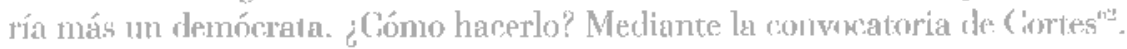

La Constitución futura le inquieta: «Nadie más inclinado a restaurar y alirmar y mejorar; nadie más tímido en alterar y renovar. Acaso éste es un achaque de mi vejez. Desconfío mucho de las teorías políticas y más de las abstractas». Lo que hay que hacer es educar, con lo que la libcrtad se afianzarán. Esto parece una muestra de burkismo jovellanista, tondencia muy fuerte en a lanque no la única. La defensa del Antiguo Régimen, en Jovellanos, viene a coinridir con la de Burke, aunque siempre en sordina, sin los tonos desaforados del pensador irlandés. Seu esto producto de la vejez, como opina el propio Jovellanos, o de los largos años de aislamiento en Bellyer, corno dice Ediuh Helmant" o de que nunca acertó a despegarse de su formación monárquico-católica, como dice 'Tateishi" ${ }^{\text {thi }}$, el caso es que Jovellanos, no obstante las audacias relativas

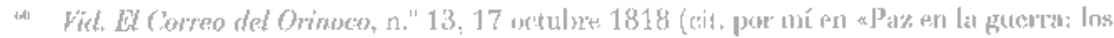

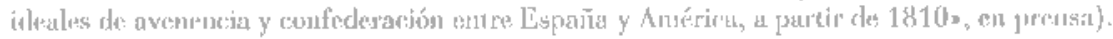

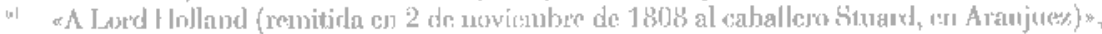
Epistolario, págs, 181-182, O.C.., vol. Y, pág. 20-24

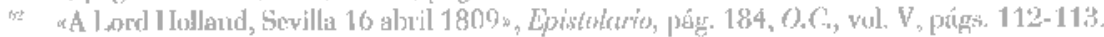

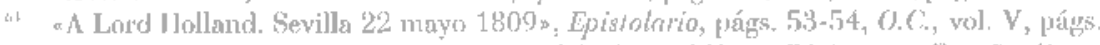

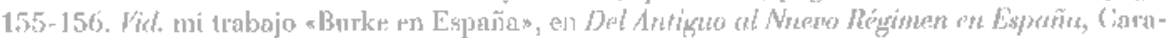
('as, Mrademia Nacional de la Historia, 1986, págs. 93-044.

in Jistellonos y Cony, op. rit, pág. 105.

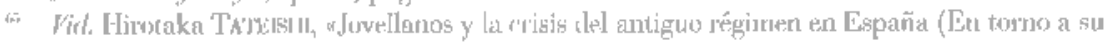

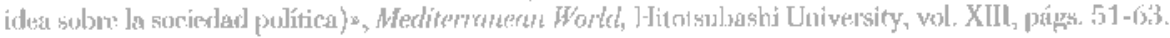


de su pensamiento, aparece como un hombre que tiene micdo. En esa misma carta, últimamente citada, Jovellanos cscribe: «Yo no temo revoluciones», pero la palabra en este punto me parece que sólo significa alborotos.

Terrible Jovellanos. Un plan que le parece exerlente, no quisicra que las Cortes lo adoptasen, por ser novedad. También en esto hay que ir poco a poco. Según él, las primeras Cortes deben limitarse solamente a preparar la representación de las siguientes, lo cual está reñido con toda idea de prudencia, o de las posibilidades de España en aquel momento. Y sin embargo, es Jovellanos demasiado inteligente, para descansar, inalterado, en posiciones pretéritas. Sabe que se trata de Cortes generales, y no sólo castellanas, y sabe también que no puede limitarse la representación a las dieciocho ciudades, que tenían voto en Cortes. En antiguos reglamentos encrentra que alguna ver, se convocó a ciudades y villas que no tenían voto en las Cortes comunes. Con este precedente, "y aún algo más con respecto a las circunstancias del día» se pucde alterar aquella norma, y convocar a 10 dos ${ }^{6,}$. lovellanos está pasando de una forma de convocatoria a otra, creyendo mantencrse en la primera. Por algo Julio Somoza le colocó entusiasta y abusivamente entre los primeros defensores españoles del sufragio universal ${ }^{67}$.

Pero su ansiedad es grande, no solamente por el curso de la guerra, de la que es restigo excepcional, sino por las imovaciones políticas que adivina. Al conde de Ayamans, el 4 de septiembre de 1810, le escribe defendiendo el principio de las dos Cámaras, para que haya doble deliberación, y se evite la precipitación en las resoluciones. De lo contrario, se desvanecerá el verdadero carácter de la monarquía española. "Lo que se adopte en estas Cortes servirá para otras, y Cortes anuales (que entonces se querrán) en una asamblea general, sin distinción de estados ni deliberación doble ni balanza que mantenga el equilibrio entre el poder ejecutico y el legislativo, caerán poco a poco en una democracia, por más que se clame por Fernando y se pronuncie el nombre de monarquía” ${ }^{\text {ti: }}$.

Cuando ya las Cortes inician sus sesiones, Jovellanos lamenta la «forma libre y confusa en que se constituyeron». Según él el ejecutivo es puramente nominal, pues de hecho, se halla refundido en el legislativo. Una sola cámara, que toma sus resoluciones de golpe, sin apenas discusión, es de temer que produzca muchos inconvenientes. Curiosa forma de razonar: Jovellanos aprueha la soberanía nacional, como doctrina de la ciencia política, pero no en un pás como

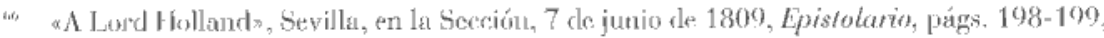
O.(., vol. V, págo. 190-199.

ir Las amergurers de Jovellanes, pág. 177

« Al Conde de Ayamans», Muros, 4 septiembre 1810. Epistolario, págs. 229-230. O.C., vol. $V$, prígs. $416-417$. 
España al que no se ha preparado para tal doctrina. Aprucba la libertad de imprenta, pero no desde el principio, sino cuando ya la Constitución esté plenamente establecida. Las teorías políticas no bastan, es necesaria la experiencia. «Las ideas de Juan Jacobo, y de Mably, y aun las de Locke, Harrington, Sidncy, elc., de que están imbuidos los pocos jóvenes que leen entre nosotros, son poco a propósito para formar la constitución que descamos». Inportante declaración, tanto en las lecturas que atribaye a los jóvenes, como en pensar que los enemigos se aprovocharán de tanta inexporicncia. Menos mal que en las Cortes está Argüelles, de quien tithe buenas referencias ${ }^{6,7}$.

Láa insurrección de Anérica le acongoja, y no comprende cómo puede ser Blanco «imo de sus más ardientes sopladores». Lo mismo que en otras materias, tambiến es ésta comprende. Jovellanos eque los hahitantes de la América tespanonla tienen derechos; peru se hace la ilusión, o quisiera hacerse la ilusión, de que las Cortes satisfarán todos sus desens. Los principios pueden ser cienos, pero lu política no es ura ciencia, no se pueden dar a aquellos habitantes lo que quieren. Jovellanos cate en el racismo. como tantes compatriotas suyos en aquellat hora. Efeetivanenter, son las castas las que le hotrorizan. Y la política inglesa: Piu fonentó la insurreceión de la América Meridional, pero ahora conlíá en lats miras benélicas del crobierno británico con respecto a España ${ }^{70}$.

Fin otra carta al mismo, sin fecha, pero de finales de 1810 , reitera y al misruo tiempo maliza algo sus posiciones anteriones. Las Gortes habían comenzado sus deliberaciomes, lo que celebra porque hen decretado la libertad de iunprenta, aunfuc todavía no conoce los términos de la ley. Pero, siempre el pero de Jovellanos, no obstante su adhesióm a la libertad de imprenta, le parece ésia prematura, porque no tenemos expericncia política, y porque los franceses, nuestros encmigos, se aprovechatún de clla, sobre todo en América. Fxpresa en este punto Jovellanos e] temor, nuty comín, al la fiérdida de América, que sería efecto de los agentes de. Napoleón en el Nucvo Mundo. Ironías del destino: este temor lo compartían también muchos españoles americanos, los cua-

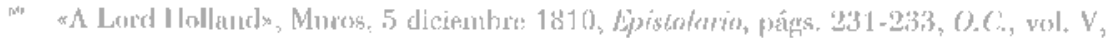

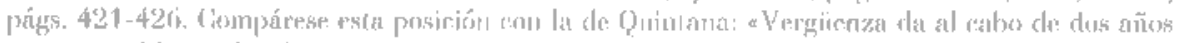

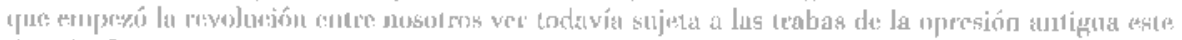

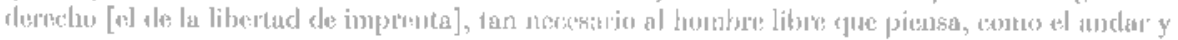

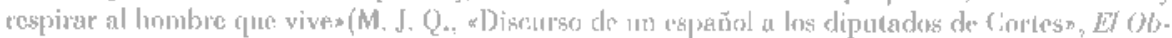

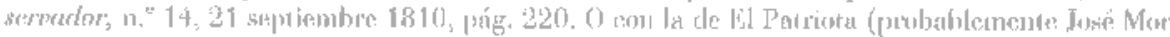

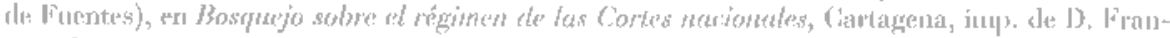

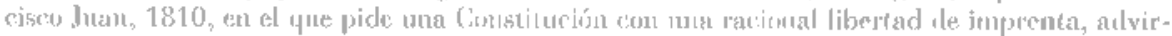

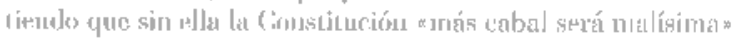

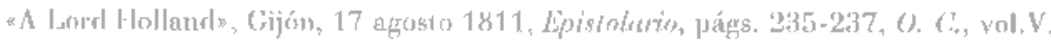
págs. $478-481$. 
les para evitar caer en manos de Napoleón, o de José I, formaron sus Juntas leales a Fernando VII, comenzando así insensiblemente su propia marcha a la Independencia.

Pero en Jovellanos lo de América, con ser verdadero, ocupa un lugar secundario en las reservas que opone a las Cortes. La libcrtad de imprenta será excelente, una vez que tengamos una buena Constitución, no antes. Se cncierra aquí Jovellanos en un verdadero sorites: no puede haber Constitución buena si antes el país no ha adquirido experiencia a través de la libertad, la de imprenta eu primer lugar. Pero sólo después de tener Constitución se podrá tener libertad de imprenta. La misma ley, buena para el futuro, es dañosa en el presente.

La organización misma de las Cortes no le gusta: una sola Cámara, con el ejecutivo sometido al legislativo, sin veto, ni derecho de revisión, ni de sanción (quiere decir, sin derecho a negar la sanción). Además, dice, las deliberaciones se hacen al golpe, sin una detenida reflexión. Yo no sé si en este punto tiene razón, o no, Jovellanos: la lectura del Diario de sesiones no nos produce esa sensación de apresuramiento, que el asturiano denuncia. Pero sabido es que cl Diario de sesiones, aunque lundamental para el estudio de las Cortes, no refleja con fidelidad lo que ocurría en el hemiciclo; y solamente a través de algunos periódicos, no de todos ni en todos los casos, podemos reconstruir el alcance de lo que allí se dijo. A pesar de la existencia de estos órganos periodísticos, muy utilizados en este sentido desde antiguo, queda que al Diario de sesiones se da valor normativo, el único que con frecuencia se tiene en cuenta, mientras que lo demás se llena de polvo, o incluso desaparece.

De nuevo descalifica a los teóricos extranjeros, en los que se basan los nuestros, Mably, Locke, Milton, "y otros teoréticos cpee no han hecho más que delirar en política». Uná vez más pudiéramos pensar que quien rechaza a Rousseau, Mably, Locke, Harrington, Sidney, Milton ${ }^{71}$, etc., difícilmente podrá ser tenido por liberal. Y sin embargo Jovellanos recuerda su Expediente de la ley agraria, y pasando a la defensa de la Iunta Central, escribe: "Blanco no ignorará que no era yo solo el que tenía en la central principios liberales y justos». De manera que defendiendo a sus colegas. Jovellanos se titula liberal, y le parece que quien no tenga en cuenta la pureza y rectitud de intenciones de los hombres de la Junta, casi todos, incurrirá en una censura «iliberal e injusta» ${ }^{72}$.

i) Jovellanos había tradurido el canto prineto del Parcíso perdido, de Milom (Obras, we Nocedal, BAE, vol. XI,VI, págs، 26-333.

72 * A Lord IJolland», Obres de Jovellanos publicadas por Nocedal, BAl, Madrid, 1952. págs. 320-321, O. (. vol, V, págs. 426-428. 
En ma rxiensa nota, puesta al palecer on 1811 a su Consulta de la convocación de Cortes, recogida en su Memoria en defensa de la Junta Central, después de decir en ella que según el derecho público de España la plenitud de la solyeranía reside en el momarca, Jovellanos explica su divergencia, si la hay, con el principio aprobado ya por las Cortes de Cádiz. En esta nota Jovellanos traza ma especie de teoría del contralo social: en una asociación de hombres que se reunen para vivir en sociedad, el poder absoluto, que solemos llamar soberanía, perienece a toda la asociación; pero ésta, al constituirse, la deległ en su representante o monarca. De manera que, paradójicamente, la soberanía del Rey significa la soberanía de la Nación. Tiene razón Jovellanos: en el Antiguo Régineru la soberanía del Rey equivale a la de la Nación, frente a rudos los cuctpos particulares. Pero en el Nuevo Régimen, que en su tiempo pugnaba por surgir en España, se produce la disociación de ambos términos, y la liberación consiguiente del estado popular. La cuestión estriba en si Jovellanos pudo darse cuenta del alcance de esta distinción, y si se ballaba dispuesto a cruzar metafóricamente el Rubicón. Jovellanos distingue entre poder ejecutivo y poder legishativo. Sólo al primero, nos dice, se le llama propianente soberano en el lengruje polídico. Las Corles estableceu las normas por las que ha de regirse la Nación, y el soberano las ejeruta; pero no de cualquier inanerd, sino con arreglo a la voluntad de la Nación, porque Jovellanos tiene bien presente el rechazo del tivano en el derecho histórico español. Salvo el equivoco del lenguaje, y lo que este equívoco esconde, psta doctrina parece nodernísima. En todo caso Jovellanos declara que acepta la autorinad de las Cortes, aunque en ol orden particular, usanfo de la libstad de opinar y escribir que hun decretado las mismas Cortes, se reserva el derecho de disentir ${ }^{\text {tit }}$.

Para el buen entendimiento de las ideas de Jovellanos, en su nomento, conviene haver la observación de que dovellanos íntimo no era conocido, ya que ni los Diarios ni las cartas eran de dominio público. Solamente Cén Bemúdez en 1814 describe los Diarios, pero se interesa sobre todo por los viajes, sin que de esta descripción emane neda recóndico ${ }^{74}$. Sólo su postura ante la convoratoria de Cortes, y su trabajo en la Junter Central san conocidos, en lo político inmediato. De aquí se deriva que el ilustrado por excelencia se conviorta en cl hombre de la revolución española, incluso en el doceañista, e inmediatamente en al moderado, el partidario de las dos cámaras. Todos quieren uvilizar su nombre, con muy joco respeto bistórico. Así le vamos a encontrar de heroldo de la

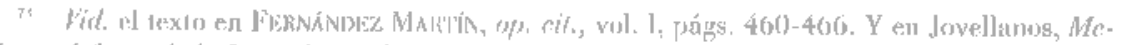

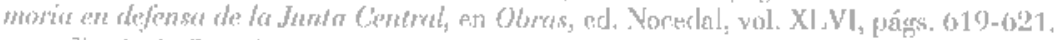

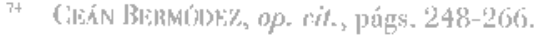


reina Cristina y de Isabel $\mathrm{II}^{75}$, antes de que Nocedal en su edición ya citada le calificue de "verdadero fundador del partido conservador o moderado» ${ }^{76}$, cosa que ya criticó .Julio Somoza ${ }^{77}$, mientras otros le hacen campeón del Senado de la Restauración ${ }^{76}$. Solamente Lord Holland en sus Sotvenirs se limita a prolongar la imagen impresionante del gran hombre ilustrado, de intachable moralidad y modestia, perseguido por la envidia y por la mediocridad de los otros ${ }^{79}$.

Acaso por América comenzó la utilización reacejonaria del nombre de Jovellanos. [no de los primeros textos, que se revuelve contra El Español, el periódico de Blanco, por su posición ante la independencia de América, el Breve registro, ironiza ante el hecho de que Blanco excluya a Jovellanos de sus diatribas contra la Junta Central, dando a entender que Jovellanos sabía lo que hacía, y no el ridículo escritor del apellido traducido ${ }^{40}$. Y sin embargo de la posición de Jovellanos ante el derecho de insurrección, en la Península, parece proceder la extensión de la idea a Anérica, que hace el mismo Blanco". La imagen de Jovellanos, gran hombre y gran patriota en medio de sus persecuciones. queda identificada a la de los realistas en Anérica, contrapuesta a la de los liberales, tanto en España como en Anérica, en El Pensador del Perú: A la Nación española, Lima 1814. Al año siguiente todos esos liberales, pero no Jovellanos, quedan englobados en el concepto tópico de los jacobinos de España ${ }^{82}$.

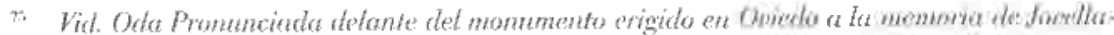

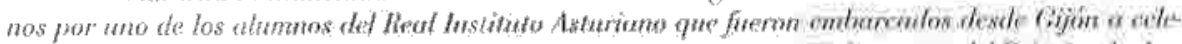

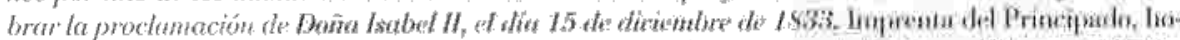

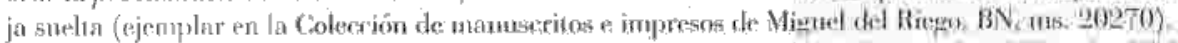

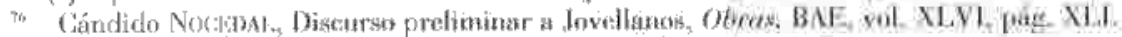

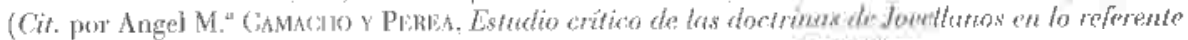
a las (ienrias Morteles y Polítres, Madrid, Jaime Ratés, 1913, páp. 202).

Fid. Julio SomozA, Jotellamos Datos peure su biogreffe, IJahoua, La Propaganda I iteraria, Madrid, Fernando Fe, 1885, págs. XvII-XvIII.

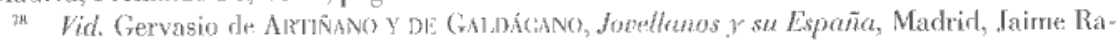
tés, 1913 , pág. 105.

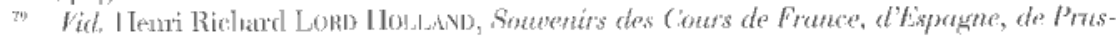
se ef de Russie écrits par... publiés par I, nord Holland son lils et traduits de l'anglais, pat E.F. Suivis du Jommal de Mistuess Ellioti (...), París, Firmin Didot Frères, 1862, págs. 68 -73 y 80.

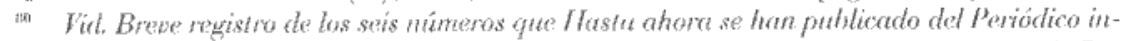
tituluto El Lspenöol. Es carra de un parriota español residente en Londies a un amieno suyo en la Penímsula, Londures, en lá imprenta de Vogel y Soludze, 1810, págs. 36-38. Fste Brene registró 1iene que ver probablemente con 13 Observator; de Londres, cuyo pritner número se cita en una nota previa.

si Vid. André Pons, ePrensa y cmancipación en Fispantanérica: El Fsipañol de Blanco-White, Londres, 1810-1814», Trienio, n 24, noviembre 1994, púgs 54-5.5.

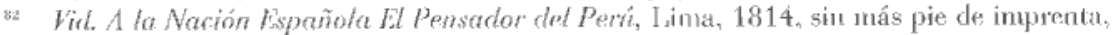
págs. iniciales, y Al Rey Nuesiro Señon: Ex Pensator del Perú, Lima, Año de 1815, 1exto, y nota 3 le: la pág. 57. 
Jovellanos contra Jovellanos. Por lo que hace a la revolución liberal, en reIáción con nuestro autor, repetiré que todo arranca de su posición neta ante la convocatoria de Cortes, Esta es la verdadera divisoria, la que nimba su nombre con al adjetivo, muy pronto sustantivo, de iiberal. Propugnó la reunión de las Cortes, defendió a la Junta Central. ¿Hizo esto último sólo por defenderse a sí mismo? No se puede negar la fuerte carga autobiográfica que hay en este oscrito. Pero creo que se trata de algo más: es el sentido de una misión, colectiva, cumplida; auncune en ella haya hahido errores. Jovellanos no podía estar de anuerdo con la urba de los enemigos de la lonta, que en cienta nantara ha pasado a dominar: los errores de la Junta han crecido, hasta borrar a la Junta misma. Y sin embargo tambión la Junta Central fize reivindicada y no sólo por Jowellanos: otro ex-vocal de la misma, Calvo de Rozas, uno de los fundadores del hilillo de la dentocracia española, expone en 1839 sus ideas: propone que las tierras de la Nación se subdividan y repartan gratis en pequeños lotes a militares, milicianos y jornalejos. L's una idea untjuga, aparecida ya en las guerras civiles de Roma, pero que en España cuando llega a su término la primerá carlista, Calvo fle Rozas atribuye a la Junta Cicntral, la cual, dice, a través de una serie do medidas trató de ir aliviando la sucrte del bajo pueblo, para preparar el futurn reparto. Si éste no se hizo, la culpa fize de los gobiernos de Fernando VII, a partir de la reacción de $1814^{\mathrm{kt}}$.

Frente al liberalismo económico, que se impuso, un pensaniento social. ¿Será éste también el caso de Jovellanos? Abundan hos lihros que le presentan intensamente dedicado a mejorar la suerte de lus dermás ${ }^{8+}$. La cosa es indudable, pero también su sentido aristocrútico de la sociedad, acaso como dice ('arlos Le Brun porque veía Pelayos en todos los reyes"i, pero también porque de él arranca precisamente d liberalismo económico en Lspaña ${ }^{g / 6}$, y purque la urmazón de su socicdad combinaba lo rancio con lo innovador. Volviendo ahora a la respuesta que diera al general Stbastiani, le dice que los españoles peleamos "por los preciosos derechos de muestro rey, nuestra religión, nuestra constitución y nuestra ibdependencia $x^{47}$, Es la famosa trinidad ideológica, archirrepeti-

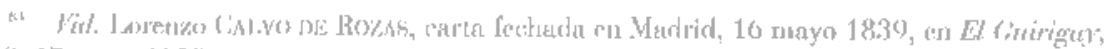
n" 118,17 minyo 18,39 .

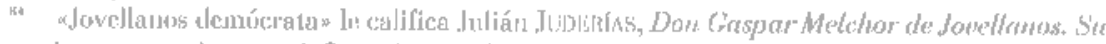

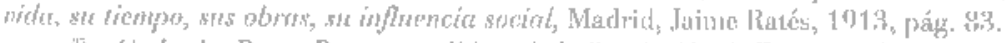

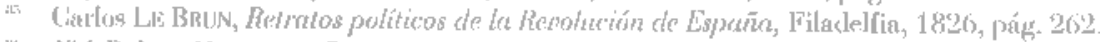

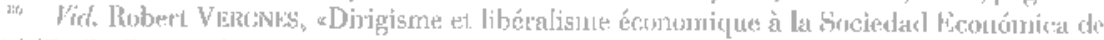

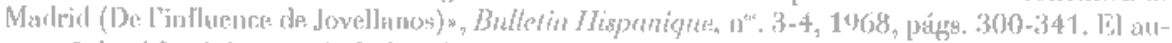

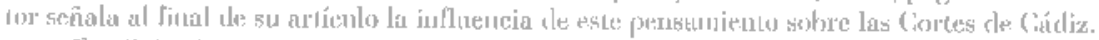

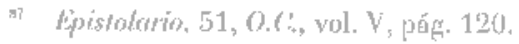


da durante la guerra de la Independencia, que lo mismo que los tres mosqueteros eran cuatro, también en Jovellanos se compone de cuatro miembros. Dios, Patria y Rey acabó siendo el lema carlista. Durante la Guerra de la Independencia esa trimidad se enumcia en Rey, Patria y Religión, y se quiere hacer descansar en ella la famosa Revolución española. El problema surge cuando aparece, como aquí, un cuarto elemento, el de la independencia nacional, o incluso

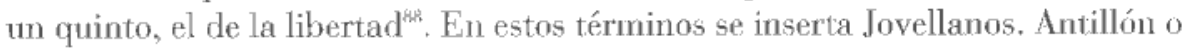
Le Brun lo ven como el hombre que abre la revolución en España. Pronto su nombre servirá de hábito a los reaccionarios, que a sí mismos se llamarán jovellánicos ${ }^{89}$. Pero para España y para América -Cortes, derecho de insurrecciónsu nombre fue providencial. Es lo que no debemos olvidar, so pena de caer, nosotros también, en anacronismo.

* Contentamulo las respuestas de Jovellanos a Sebastiani y a Cabartús, Dérozier habla de la cambigüedad s del asturiano, palabra que no me parece del todo acertada. Jovellanos no es anbiguo en su patriotismo o en sus posiciones políticas; pero el liempo va mucho más rápido de lo que él mismo pudiera imaginar. Fid. Albert Dírozilir, Liscritores políticos españoles (1759-18.54), Madrid, Turnes, 1975, págs. $27-28$.

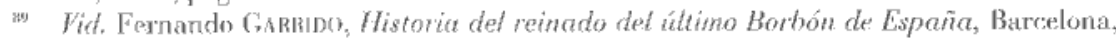
Salvador Manero, 1868, pág. 489, sobre la aparición de una hoja en ocubre de 1840, que denumriaba los planes monárupuicos de los jovellenistas, sociedad secreta aparecida ya en 1820, según el antor. En la hoja figuraban los nombies de Istúriz, Alcalá Galiano, Muñoz Malflonado y Manuel y Luis González Bravo. Inos dos últimos lo negaron. Pero esta sociedad en 1820 todavía no había adoptado el nombre de Jovellanos: se llanaba Sociedad del Anillo de Oro. 